DOI: $10.19195 / 2300-7729.37 .7$

\author{
DOROTA GRABOWSKA \\ ORCID: 0000-0002-2727-6942 \\ Uniwersytet Warszawski
}

\title{
Ewolucja zadań nauczycieli bibliotekarzy w dydaktyce szkolnej
}

Zmieniające się programy i podstawy programowe zawsze wpływały na pracę nauczycieli bibliotekarzy. Zakładano, że będą oni, w mniejszym lub większym stopniu, kształtowali umiejętności niezbędne uczniom.

W dwudziestoleciu międzywojennym nie było jeszcze nauczycieli bibliotekarzy. Bibliotekami szkolnymi opiekowali się bezpłatnie nauczyciele ${ }^{1}$, ale to wówczas zbudowano podwaliny pod rozwój bibliotek szkolnych. Już w 1919 roku ukazał się pierwszy okólnik Ministerstwa Wyznań Religijnych i Oświecenia Publicznego, w którym zwracano uwagę na porządkowanie księgozbiorów bibliotek szkół średnich ${ }^{2}$. Wydano także Instrukcję w sprawie biblioteki dla młodzieży szkót średnich ${ }^{3}$. We współpracy ze Związkiem Bibliotekarzy Polskich podejmowane były próby kształcenia opiekunów bibliotek szkolnych. Wydano pierwsze podręczniki bibliotekarstwa szkolnego ${ }^{4}$. Programy szkolne zwracały uwagę na budzenie zainteresowań czytelniczych i umiejętność czytania. Duży wkład w rozwój bibliotek szkolnych i zawodu nauczyciela bibliotekarza wniosła Helena Radlińska $^{5}$ - propagowała przekonanie, że pracownicy bibliotek szkolnych powinni włączać się w proces dydaktyczny i krzewić czytelnictwo. Zwracała uwagę na samokształcenie. Twierdziła, że „Biblioteka szkolna — jest konieczna jako miejsce spotkania z wieloma książkami i jako placówka bibliotekarza-wychowawcy, który dba, by się książkom i z książkami dobrze działo w szkole"6. Uważała, że to bi-

1 J. Andrzejewska, Bibliotekarstwo szkolne. Teoria i praktyka, t. 1. Organizacja biblioteki, Warszawa 1996, s. 17.

2 Ibidem, s. 16.

3 Ibidem.

4 J. Bornsteinow, Jak urządzić bibliotekę szkolna i domową?, Warszawa 1927; P. Tłuczek, Prowadzenie biblioteki szkolnej, Warszawa 1930; J. Filipkowska-Szemplińska, Organizacja bibliotek szkolnych, Warszawa 1930; W. Dąbrowska, Biblioteka szkolna, Warszawa 1939.

${ }^{5}$ H. Radlińska, Zadania biblioteki szkolnej, Warszawa 1937.

${ }^{6}$ H. Radlińska, Książka wśród ludzi, Warszawa 2003, s. 144. 
blioteka szkolna powinna dostarczać uczniom narzędzi pracy umysłowej, ułatwiać szukanie odpowiedzi na pytania, które stają przed nimi w związku z uczeniem się i dojrzewaniem, wprowadzać ich w sposoby zdobywania wiedzy w szkole. Wśród tematów, które powinny być omawiane w pracy z uczniami, wymieniała: nauczanie o książce (o jej powstawaniu, pracy pisarzy, szacie graficznej), umiejętności szukania informacji w książce i obchodzenia się z nią, typy książek, najważniejsze wydawnictwa, świadome i celowe czytanie, odczuwanie piękna, radowanie się i wzruszanie losami i przeżyciami ludzkimi. H. Radlińska po wojnie opublikowała czwarte wydanie książki Książka wśród ludzi (1946), kontynuując rozpowszechnianie swoich przekonań, również tych dotyczących bibliotek szkolnych.

Druga wojna światowa przyniosła olbrzymie straty w zbiorach bibliotek szkolnych. Sięgały one 90\% w szkołach powszechnych i 75\% w szkołach średnich ${ }^{7}$. Po wojnie sytuacja bibliotek szkolnych zaczęła ulegać zmianie ${ }^{8}-$ dużo uwagi poświęcano ich rozwojowi. Od 1945 roku realizowane były centralne zakupy do bibliotek szkolnych (szkoły podstawowe do 1960 roku, szkoły średnie do $1955 \mathrm{roku})^{9}$. Należy zauważyć, że do bibliotek szkolnych trafiały przede wszystkim przekłady literatury radzieckiej. Dekret z 17 kwietnia 1946 roku o bibliotekach i opiece nad zbiorami bibliotecznymi włączył biblioteki szkolne do ogólnokrajowej sieci bibliotecznej. Programy edukacyjne treści dotyczące ogólnych wiadomości o książce i zasad pracy umysłowej powierzały nauczycielom języka polskiego. Z takim rozwiązaniem mamy do czynienia w Programie ośmioklasowej szkoty podstawowej ${ }^{10} \mathrm{z} 1947$ roku. Bibliotekarze w bibliotekach szkolnych i pedagogicznych zaczęli być zatrudniani w 1957 roku$^{11}$. Był to przełomowy rok dla zawodu bibliotekarza w bibliotece szkolnej, ponieważ Instrukcja z dnia 13 marca 1957 roku w sprawie bibliotek szkolnych i pedagogicznych nadała bibliotekarzowi szkolnemu status pedagoga wchodzącego w skład rady pedagogicznej ${ }^{12}$. W szkołach liczących czterystu pięćdziesięciu uczniów przewidywano zatrudnienie bibliotekarza w wymiarze trzydziestu sześciu godzin tygodniowo ${ }^{13}$.

Duży wkład w kształtowanie zawodu nauczyciela bibliotekarza miała Emilia Białkowska, która była zaangażowana w organizowanie kursów przygotowujących bibliotekarzy do zawodu, zwracała uwagę na ich usługową funkcję w stosunku do procesu nauczania ${ }^{14}$. Jeszcze w Programie nauczania w szkole podstawowej z 1959 roku nauczanie podstawowych wiadomości o książce spoczywało

7 J. Andrzejewska, op. cit., s. 17.

8 R. Piotrowska, Edukacja informacyjna w polskiej szkole, Warszawa 2011, s. 54.

9 Ibidem, s. 17.

10 Program ośmioklasowej szkoty podstawowej, Warszawa 1947.

11 J. Andrzejewska, op. cit., s. 14.

12 A. Radziejowska, Bibliotekarze szkolni - brak integracji zawodu, „Przegląd Biblioteczny" 1987, z. 3/4, s. 392.

13 Ibidem.

14 E. Białkowska, Praca pedagogiczna z czytelnikami w bibliotece szkolnej, Warszawa 1964, s. 10. 
na polonistach ${ }^{15}$. Oni odpowiadali za umiejętności związane z: posługiwaniem się podręcznikami, wydawnictwami popularnonaukowymi, czasopismami oraz korzystaniem z biblioteki, słowników, encyklopedii. Od 1961 roku weszło w życie Zarządzenie Ministra Oświaty określające kwalifikacje (pedagogiczne i bibliotekarskie), wymagane przy egzaminie na bibliotekarza szkolnego ${ }^{16}$, ale nadal za realizację treści bibliotekarskich odpowiedzialni byli nauczyciele języka polskiego. Treści dotyczące książki, czytelnictwa i samokształcenia zdecydowanie poszerzano. Od 1963 roku miał obowiązywać Program nauczania ośmioklasowej szkoły podstawowej (wydano go w 1964 roku) ${ }^{17}$. W części dotyczącej języka polskiego w klasach od piątej do ósmej wprowadzono „Czytelnictwo i podstawy samokształcenia”. Uwzględniono tam wiedzę dotyczącą: budowy książki, jej historii, procesu powstania, a także upowszechniania, opisów bibliograficznych książki oraz czasopisma, różnych rodzajów notatek i sposobów ich opracowania. Dodatkowo zakładano, że uczniowie klas ósmych zostaną zapoznani między innymi z elementami bibliofilstwa i warsztatem służby informacyjno-bibliograficznej w nowoczesnej bibliotece ${ }^{18}$. W Programie wyszczególniono ponadto umiejętności, nawyki i przyzwyczajenia. Wśród nich wymieniono: ćwiczenia w posługiwaniu się tekstem książki, wybieranie i zaznaczanie cytatów, korzystanie z czasopism, aparatu pomocniczego w książce, wydawnictw encyklopedycznych, katalogów, zbieranie urywków na dany temat, notowanie materiałów z książek i czasopism, audycji i filmów oświatowych, korzystanie z encyklopedii i słowników specjalnych, sporządzanie skróconego opisu bibliograficznego dzieła, zbieranie materiałów na dany temat (drogą poszukiwań bibliograficznych), korzystanie z katalogów pomocniczych i innych źródeł tekstowo-bibliograficznych. Za realizację zagadnień z bloku „Czytelnictwo i podstawy samokształcenia” dalej odpowiedzialni byli nauczyciele języka polskiego.

W latach siedemdziesiątych XX wieku uznano pedagogiczny charakter pracy bibliotekarzy szkolnych. Zarządzenie Ministra Oświaty i Wychowania ${ }^{19}$ wprowadziło tytuły zawodowe: nauczyciela bibliotekarza i nauczyciela dyplomowanego bibliotekarza. Uznano, że będą oni odpowiedzialni za przysposobienie czytelnicze i informacyjne realizowane indywidualnie i na lekcjach bibliotecznych przy współpracy z innymi nauczycielami (zwłaszcza polonistami). Nowelizacja programu ${ }^{20} \mathrm{w}$ dziale „Czytelnictwo i podstawy samokształcenia” nie wprowadzała zasadniczych zmian, jedynie doprecyzowywała niektóre zagadnienia ${ }^{21}$.

15 Program nauczania w szkole podstawowej, Warszawa 1959, s. 165.

16 Dz. Urz. Min. Ośw. 1961, nr 5, poz. 46.

17 Program nauczania ośmioklasowej szkoły podstawowej, Warszawa 1964.

18 A. Radziejowska-Hilchen, Edukacja czytelnicza i medialna, [w:] Ksiązka i biblioteka w środowisku edukacyjnym, Warszawa 2002, s. 147.

19 Dz. Urz. Min. Ośw. i Wych. 1973, nr 12, poz. 100.

20 Program nauczania ośmioklasowej szkoły podstawowej. Język polski: klasy V-VIII, Warszawa 1974.

${ }^{21}$ B. Staniów, Biblioteka szkolna dzisiaj, Warszawa 2012, s. 55. 
Kolejne programy przysposobienia czytelniczego zostały opracowane przez Instytut Programów Szkolnych Ministerstwa Oświaty i Wychowania i pojawiły się w programach szkoły podstawowej od roku szkolnego 1983/198422, a ponadpodstawowych od 1986/198723. Szczególną uwagę zwrócono na rozwój kultury czytelniczej oraz samokształcenie. Za ważne uznano w nich pokazanie znaczenia słowa drukowanego w życiu zarówno jednostki, jak i społeczeństwa, a także zwrócono uwagę na rolę instytucji gromadzących i udostępniających zbiory oraz informacje. Zakładano realizację takich zagadnień, jak: kształtowanie aktywności poznawczej uczniów, umiejętności posługiwania się książką i innymi dokumentami jako źródłami wiedzy i przeżyć emocjonalno-estetycznych, kształtowanie upodobań i przyzwyczajeń czytelniczych uczniów, umiejętności posługiwania się książką, czasopismem i innymi dokumentami w oparciu o znajomość techniki pracy z dokumentem piśmienniczym oraz techniką biblioteczną ${ }^{24}$. Za realizację przysposobienia czytelniczego odpowiedzialni mieli być wszyscy nauczyciele. Zakładano, że treści te pojawią się w realizowanych przez nich programach przedmiotów, podkreślono przy tym szczególną rolę biblioteki szkolnej, która miała stanowić podstawowy warsztat pracy umysłowej uczniów i nauczycieli. Na przysposobienie czytelnicze i informacyjne przeznaczono łącznie dwadzieścia godzin lekcyjnych: w klasach pierwszych i drugich po jednej godzinie rocznie, w klasach trzecich i czwartych po dwie, w piątych i szóstych po trzy i po cztery godziny w klasach siódmej i ósmej. Materiały nauczania przysposobienia czytelniczego i informacyjnego w szkole podstawowej zostały podzielone na cztery działy: wiedza o dokumencie, wiedza o instytucjach gromadzących i udostępniających dokumenty, nośniki i narzędzia informacji, wybrane zagadnienia techniki i higieny pracy umysłowej ${ }^{25}$. Za podstawowy cel pracy pedagogicznej nauczyciela bibliotekarza uznano rozwijanie kultury czytelniczej uczniów. Wśród szczegółowych umiejętności wymieniono rozwijanie: zainteresowań i motywacji czytelniczej, aktywności i kompetencji czytelniczych, technik pracy z książką, bibliotecznych oraz technik i higieny pracy umysłowej ${ }^{26}$.

$\mathrm{W}$ programie dla liceum ${ }^{27}$ przewidziano na przysposobienie czytelnicze i informacyjne łącznie dwanaście godzin (po trzy godziny w klasach od pierwszej do czwartej), w technikum zawodowym (pięcioletnim) również dwanaście godzin (po dwie godziny w klasach od pierwszej do trzeciej i po trzy w klasach od

22 Program szkoly podstawowej. Przysposobienie czytelnicze i informacyjne, Warszawa 1983.

23 Program liceum ogólnokształcacego oraz liceum zawodowego i technikum. Przysposobienie czytelnicze i informacyjne, Warszawa 1985.

24 Program szkoty podstawowej. Przysposobienie czytelnicze i informacyjne...

25 D. Grabowska, Podstawa programowa inspiracja do wspótpracy nauczycieli bibliotekarzy z nauczycielami ksztatcenia zintegrowanego i języka polskiego, „Poradnik Bibliotekarza” 2013, nr 9, s. 4-10.

26 Program szkoły podstawowej. Przysposobienie czytelnicze i informacyjne..., s. 8.

27 Program liceum ogólnokształcacego oraz liceum zawodowego i technikum. Przysposobienie czytelnicze i informacyjne... 
czwartej do piątej) i sześć godzin w trzyletnim technikum zawodowym (po dwie godziny w każdej klasie). Realizowane zagadnienia, tak jak w szkole podstawowej, związane były z: poznaniem biblioteki i gromadzonych w niej dokumentów, organizacją warsztatu pracy samokształceniowej ucznia oraz technikami pracy umysłowej opartej na dokumencie bibliotecznym. Przysposobienie czytelnicze $\mathrm{i}$ informacyjne prowadzone miało być przez nauczyciela bibliotekarza $\mathrm{w}$ formie obowiązkowych zajęć pozalekcyjnych ${ }^{28}$.

Po 1989 roku przystąpiono do reformy szkolnictwa, między innymi, wprowadzając minima programowe, przysposobienie czytelnicze i informacyjne ${ }^{29}$ zmniejszono do piętnastu godzin. Realizacji tych zagadnień nie umieszczono w planach nauczania, miały być one realizowane podczas przypadkowych lekcji bibliotecznych lub na zastępstwach. W szkołach ponadpodstawowych obowiązywał nadal program z 1985 roku, który przeznaczał na przysposobienie czytelnicze i informacyjne dwanaście godzin w ciągu czterech lat w liceach i pięciu lat w technikach oraz sześć godzin dla trzyletnich szkół zawodowych. Treści realizowanych zagadnień nie uległy zmianie.

Reforma z 1 września 1999 roku zmieniła cały system szkolny, typy szkół, zakres nauczanych treści, zasady nauczania, zakładała również zmianę sposobu nauczania na bardziej aktywny i świadomy ${ }^{30}$. Cele edukacyjne i zadania szkoły zostały wyznaczone w podstawie programowej wychowania przedszkolnego oraz kształcenia ogólnego w poszczególnych typach szkół ${ }^{31}$. Edukacja w szkole podstawowej przebiega $w$ dwóch etapach (etap pierwszy: klasy od pierwszej do trzeciej, tzw. nauczanie zintegrowane; etap drugi: klasy od czwartej do szóstej i od pierwszej do trzeciej — gimnazjum). Od drugiego etapu kształcenia pojawiły się ścieżki edukacyjne, czyli zestawy treści i umiejętności o istotnym znaczeniu poznawczym i wychowawczym, których realizacja miała odbywać się w ramach nauczania przedmiotów lub w postaci odrębnych zajęćc ${ }^{32}$. Jedną ze ścieżek była „Edukacja czytelnicza i medialna”, obejmująca treści, które były dotąd realizowane w przysposobieniu czytelniczym. Za realizację poszczególnych ścieżek odpowie-

28 Ibidem, s. 7.

29 Program szkoly podstawowej. Przysposobienie czytelnicze i informacyjne, Warszawa 1990.

30 A. Radziejowska-Hilchen, op. cit., s. 140.

31 Rozporządzenie Ministra Edukacji Narodowej z dnia 15 lutego 1999 roku w sprawie podstawy programowej kształcenia ogólnego, Dz.U. 1999, nr 14, poz. 129. Rozporządzenie to straciło moc z dniem 1 września 2001 roku, wtedy zaczęło obowiązywać Rozporządzenie Ministra Edukacji Narodowej z dnia 21 maja 2001 roku, Dz.U. 2001, nr 61, poz. 625, które nie zmieniło podstawy programowej edukacji czytelniczej i medialnej.

32 W szkole podstawowej wprowadzono następujące ścieżki edukacyjne: edukacja czytelnicza i medialna, edukacja ekologiczna, edukacja prozdrowotna, wychowanie do życia w społeczeństwie: wychowanie do życia w rodzinie, wychowanie regionalne - dziedzictwo kulturowe w regionie, wychowanie patriotyczne i obywatelskie. W liceum zaś: edukacja czytelnicza i medialna, edukacja ekologiczna, edukacja europejska, edukacja filozoficzna, edukacja prozdrowotna, edukacja regionalna - dziedzictwo kulturowe w regionie, wychowanie do życia w rodzinie. 
dzialni byli wszyscy nauczyciele. Nauczyciel bibliotekarz również mógł włączać się w realizację różnych ścieżek. Zakładano, że korzystanie z biblioteki, doskonalenie umiejętności wyszukiwania informacji będzie realizowane w sposób regularny w ciągu całego procesu dydaktycznego. Celem edukacji czytelniczej i medialnej miało być przygotowanie do: samodzielnego poszukiwania potrzebnych informacji i materiałów, odbioru informacji rozpowszechnianych przez media, świadomego i odpowiedzialnego korzystania ze środków masowej komunikacji (telewizji, komputerów, prasy itp.) oraz kształtowanie postawy szacunku dla polskiego dziedzictwa kulturowego w związku z globalizacją kultury masowej. Osiągnięciami, które powinni posiąść uczniowie podczas realizacji tej ścieżki, miały być: czytanie dla zdobycia wiadomości i zaspokajania potrzeb poznawczych, poszukiwanie oraz wykorzystanie informacji z encyklopedii, słowników, innych wydawnictw i dokumentów pozaksiążkowych (medialnych), wyszukiwanie materiałów na określony temat za pomocą katalogów i kartotek, rozpoznawanie elementów języka mediów w różnych rodzajach komunikatów, wskazywanie tych, które przedstawiają rzeczywistość realną oraz fikcję, rozróżnianie między obiektywną relacją a komentarzem, posługiwanie się podstawowymi urządzeniami medialnymi, a także umiejętność krytycznej analizy wartości oferty mediów i dokonywania właściwego wyboru w korzystaniu ze środków masowej komunikacji.

Kolejne zmiany przyniosła podstawa programowa obowiązująca od 2009 roku $^{33}$. Rozporządzenie zaczęło obowiązywać od roku akademickiego 2009/2010 od pierwszej klasy, wdrażano je sukcesywnie. W wychowaniu przedszkolnym (załącznik nr 1 - Podstawa programowa wychowania przedszkolnego dla przedszkoli, oddziałów przedszkolnych $w$ szkołach podstawowych oraz innych form wychowania przedszkolnego) wśród umiejętności wymieniono kształtowanie gotowości do nauki czytania i pisania. Z punktu widzenia bibliotekarzy warto podkreślić, że dziecko kończące przedszkole powinno wykazywać zainteresowanie czytaniem i pisaniem oraz przejawiać gotowość do nauki czytania i pisania. Jeszcze na jedną aktywność warto zwrócić uwagę - słucha na przykład opowiadań, baśni i rozmawia o nich oraz interesuje się książkami. Aby możliwe było wykształcenie tych umiejętności, dziecko musi poznać różnorodną literaturę. Warto ułatwiać odkrywanie tego, co sprawia mu największą przyjemność, a większe sukcesy w tym zakresie można odnieść, kiedy bibliotekarze wesprą nauczycieli wychowania przedszkolnego.

Kolejne umiejętności, które mogą być kształtowane przy wsparciu nauczycieli bibliotekarzy, pojawiają się w Podstawie programowej ksztatcenia ogólnego dla szkót podstawowych (załącznik nr 2). Wśród umiejętności zdobywanych przez ucznia w trakcie kształcenia ogólnego w szkole podstawowej wymienia się mię-

33 Rozporządzenie Ministra Edukacji Narodowej z dnia 23 grudnia 2008 roku w sprawie podstawy programowej wychowania przedszkolnego oraz kształcenia ogólnego w poszczególnych typach szkół, Dz.U. 2009, nr 4, poz. 17. 
dzy innymi czytanie - rozumiane jako prosta czynność, jako umiejętność rozumienia, wykorzystywania i przetwarzania tekstów w zakresie umożliwiającym zdobywanie wiedzy, rozwój emocjonalny, intelektualny i moralny oraz uczestnictwo w życiu społeczeństwa. Mówi się również o umiejętności komunikowania się w języku ojczystym i w języku obcym, zarówno w mowie, jak i w piśmie; posługiwania się nowoczesnymi technologiami informacyjno-komunikacyjnymi, w tym także w celu wyszukiwania i korzystania z informacji; uczenia się jako sposobie zaspokajania naturalnej ciekawości świata, odkrywania swoich zainteresowań i przygotowania do dalszej edukacji, a ponadto umiejętności pracy zespołowej.

Za obowiązek każdego nauczyciela, w tym nauczyciela bibliotekarza, uznano kształtowanie umiejętności posługiwania się językiem polskim i dbałość o wzbogacanie zasobu słownictwa uczniów. Warto w tym miejscu przypomnieć, że zasób słownictwa wzrasta podczas czytania - zarówno cichego, jak i głośnego. Za ważne zadanie uznano przygotowanie uczniów do życia w społeczeństwie informacyjnym, a wymaga to umiejętności wyszukiwania, porządkowania i wykorzystania informacji z różnych źródeł, z zastosowaniem technologii informacyjno-komunikacyjnych, na zajęciach z różnych przedmiotów. Można to odczytać jako zachętę do współpracy wszystkich nauczycieli z bibliotekarzami. Bez dobrze wyposażonej biblioteki z dobrym warsztatem informacyjnym nie da się kształtować powyższych umiejętności, co również zostało zapisane w podstawie: „Realizację powyższych celów powinna wspomagać dobrze wyposażona biblioteka szkolna, dysponująca aktualnymi zbiorami, zarówno w postaci księgozbioru, jak i w postaci zasobów multimedialnych". Nauczycieli wszystkich przedmiotów obliguje się także do poświęcenia dużej uwagi edukacji medialnej, czyli wychowaniu uczniów do właściwego odbioru i wykorzystania mediów.

Podstawa programowa zakłada, że uczeń kończący klasę trzecią korzysta z informacji, analizuje i interpretuje teksty kultury oraz tworzy wypowiedzi. Pierwszy punkt dotyczy korzystania z informacji, a pamiętamy, że biblioteka w szkole to centrum informacji. Do ważnych umiejętności zaliczono uważne słuchanie wypowiedzi i korzystanie z przekazywanych informacji, czytanie i rozumienie tekstów przeznaczonych dla dzieci na pierwszym etapie edukacyjnym i wyciąganie z nich wniosków, wyszukiwanie w tekście potrzebnych informacji i w miarę możliwości korzystanie ze słowników i encyklopedii przeznaczonych dla dzieci danego etapu kształcenia. Wśród analizy i interpretacji tekstów kultury wymienia się: przejawianie wrażliwości estetycznej, rozszerzanie zasobów słownictwa poprzez kontakt z dziełami literackimi; zaznaczanie wybranych fragmentów w tekście literackim, określanie czasu i miejsca akcji, wskazanie głównych bohaterów; czytanie tekstów i recytowanie wierszy, z uwzględnieniem interpunkcji i intonacji. Mówi się również o wykształceniu potrzeby kontaktu z literaturą i sztuką dla dzieci, czytania wybranych książek, wypowiadania się na ich temat. To właśnie nauczyciel bibliotekarz powinien śledzić rynek wydawniczy dla dzieci i młodzieży i informować o tym, co się na nim dzieje, zarówno nauczycieli, jak i uczniów. Sam w miarę możliwości 
powinien promować, chociażby za pomocą booktalkingu, nowości i wartościową literaturę oraz inne dokumenty dla dzieci i młodzieży. Nauczyciel bibliotekarz może też wspierać nauczyciela nauczania zintegrowanego w kształtowaniu wśród uczniów umiejętności tworzenia wypowiedzi w formie ustnej i pisemnej (tworzenie kilkuzdaniowych wypowiedzi, krótkich opowiadań i opisów, listów, życzeń, zaproszeń). W Zalecanych warunkach $i$ sposobach realizacji znalazł się zapis, że ważnym celem edukacji polonistycznej jest rozwijanie u dzieci zamiłowania do czytelnictwa poprzez słuchanie pięknego czytania i rozmawianie o przeczytanych utworach oraz korzystanie z bibliotek (na przykład biblioteki szkolnej).

$\mathrm{Na}$ drugim etapie edukacji w szkole podstawowej w klasach od czwartej do szóstej podstawa programowa zakłada doskonalenie: odbioru wypowiedzi i wykorzystywania zawartych w nich informacji, analizy i interpretacji tekstów kultury oraz tworzenia wypowiedzi. Realizacja tych ogólnych celów nie jest możliwa bez korzystania ze zbiorów biblioteki, a bibliotekarz może wspierać polonistę przy doskonaleniu umiejętności.

W Podstawie programowej kształcenia ogólnego dla gimnazjów i szkół ponadgimnazjalnych, których ukończenie umożliwia uzyskanie świadectwa dojrzatości po zdaniu egzaminu maturalnego (załącznik nr 4) wśród umiejętności znalazły się między innymi:

- czytanie - umiejętność rozumienia, wykorzystywania i refleksyjnego przetwarzania tekstów, w tym tekstów kultury, prowadząca do osiągnięcia własnych celów, rozwoju osobowego oraz aktywnego uczestnictwa w życiu społeczeństwa,

— myślenie naukowe - umiejętność wykorzystywania wiedzy o charakterze naukowym do identyfikacji i rozwiązywania problemów,

— umiejętność komunikowania się w języku ojczystym i językach obcych, zarówno w mowie, jak i w piśmie,

- umiejętność sprawnego posługiwania się nowoczesnymi technologiami informacyjno-komunikacyjnymi,

— umiejętność wyszukiwania, selekcjonowania i krytycznej analizy informacji,

- umiejętność rozpoznawania własnych potrzeb oraz uczenia się,

— umiejętność pracy zespołowej.

W kształtowanie tych umiejętności jak najbardziej mogli włączyć się nauczyciele bibliotekarze. To oni mogą wspierać uczniów przy realizowaniu projektów, dostarczać niezbędnych dokumentów.

Założono, że ważnym zadaniem szkoły jest przygotowanie uczniów do życia w społeczeństwie informacyjnym. Nauczyciele powinni stwarzać warunki do nabywania umiejętności wyszukiwania, porządkowania i wykorzystywania informacji z różnych źródeł, z zastosowaniem technologii informacyjno-komunikacyjnych. Ten zapis również należy odczytać jako zachętę do współpracy z nauczycielem bibliotekarzem. W podstawie znalazł się ważny zapis dotyczący biblioteki szkolnej: 
realizację powyższych celów powinna wspomagać dobrze wyposażona biblioteka szkolna, dysponująca aktualnymi zbiorami, zarówno w postaci księgozbioru, jak i w postaci zasobów multimedialnych. Nauczyciele wszystkich przedmiotów powinni odwoływać się do zasobów biblioteki szkolnej i współpracować z nauczycielami bibliotekarzami w celu wszechstronnego przygotowania uczniów do samokształcenia i świadomego wyszukiwania, selekcjonowania i wykorzystania informacji.

Podkreślono rosnącą rolę środków społecznego przekazu i znaczenie edukacji medialnej (wychowania uczniów do właściwego odbioru i wykorzystania mediów). To także obszar, który nie powinien być obcy nauczycielowi bibliotekarzowi.

W gimnazjum oraz szkołach ponadgimnazjalnych i zasadniczych szkołach zawodowych uczniowie powinni nabyć umiejętności umożliwiające odbiór wypowiedzi i wykorzystanie zawartych w nich informacji, analizowania i interpretacji tekstów kultury oraz tworzenia wypowiedzi.

Podstawa programowa nie przydzieliła nauczycielom bibliotekarzom godzin do pracy z uczniami, ale równocześnie zobowiązywała innych nauczycieli do współpracy z nauczycielem bibliotekarzem.

Od roku szkolnego 2017/2018 w klasach pierwszej, czwartej i siódmej zaczęła obowiązywać nowa podstawa programowa ${ }^{34}$, w której w załącznikach określono ramy kształcenia dla: wychowania przedszkolnego (załącznik nr 1), szkoły podstawowej (załącznik nr 2), szkoły podstawowej - dla uczniów z niepełnosprawnością intelektualną w stopniu umiarkowanym lub znaczącym (załącznik nr 3), branżowej szkoły pierwszego stopnia (załącznik nr 4), szkoły specjalnej przysposabiającej do pracy (załącznik nr 5) i szkoły policealnej (załącznik nr 6).

Założono, że wychowanie przedszkolne będzie wspierało całościowy rozwój dziecka (opieka, wychowanie, nauczanie - uczenie się). Możemy tam odnaleźć ustalenia, w realizację których powinni włączyć się bibliotekarze. Dzieci w tym wieku mają uczyć się przez zabawę. W aranżacji przestrzeni proponuje się urządzanie między innymi kącików czytelniczych. W obszarze poznawczym zwrócono uwagę, że dzieci powinny odróżniać elementy świata fikcji od realnej rzeczywistości i byty rzeczywiste od medialnych. Do umiejętności, które powinny posiąść, zaliczono objaśnianie kolejnych zdarzeń w prostych historyjkach obrazkowych, a wśród samodzielnych aktywności poznawczych wymieniono na przykład oglądanie historyjek. Bibliotekarze mogą w grupach przedszkolnych (zerówkach przedszkolnych) czytać i opowiadać krótkie historie, uzupełniając je obrazkami, rekwizytami, ruchem, mimiką lub gestem. Zabawa książką i z książką powinna być obecna już na tym etapie rozwoju dzieci.

34 Rozporządzenie Ministra Edukacji Narodowej z dnia 14 lutego 2017 roku w sprawie podstawy programowej wychowania przedszkolnego oraz podstawy programowej kształcenia ogólnego dla szkoły podstawowej, w tym dla uczniów z niepełnosprawnością intelektualną w stopniu umiarkowanym lub znacznym, kształcenia ogólnego dla szkoły specjalnej przysposabiającej do pracy oraz kształcenia ogólnego dla szkoły policealnej, Dz.U. z 24 lutego 2017 roku, poz. 356. 
W Podstawie programowej kształcenia ogólnego dla szkoły podstawowej wyróżniono dwa etapy edukacji: klasy od pierwszej do trzeciej (kształcenie zintegrowane) i klasy od czwartej do szóstej. Nauczycielom bibliotekarzom nie przyznano godzin do realizacji, nie ma również wydzielonych treści, za które mogliby odpowiadać, ale i tutaj pojawiają się zagadnienia, które powinny być realizowane przez nauczycieli bibliotekarzy, a przynajmniej we współpracy z nimi. Zadaniem szkoły podstawowej jest wprowadzenie w świat literatury i ugruntowanie zainteresowań czytelniczych. Wyraźnie mówi się o wyposażeniu uczniów w kompetencje czytelnicze, które pozwolą krytycznie odbierać utwory literackie i inne teksty kultury. Nauczyciele bibliotekarze powinni włączyć się w działania mające na celu rozbudzanie u uczniów zamiłowania do czytania oraz zwiększanie ich aktywności czytelniczej, wspierać kształtowanie postaw dojrzałych i odpowiedzialnych czytelników, przygotowywać ich do „otwartego dialogu z dziełem literackim”35.

W Podstawie programowej ksztatcenia ogólnego dla szkoły podstawowej zwrócono uwagę na ważną rolę bibliotek: „W procesie kształcenia i wychowania wskazuje rolę biblioteki (szkolnej, publicznej, naukowej i in.) oraz zachęca do podejmowania indywidualnych prób twórczych" ${ }^{36}$. Tak duży nacisk na kompetencje czytelnicze wynika z przekonania, że wpływają one na sukces uczniów w szkole, ułatwiają pokonywanie ograniczeń i trudności, które wynikają między innymi z barier środowiskowych. Czytanie uznaje się za jedną z najważniejszych umiejętności zdobywaną w procesie kształcenia. W podstawie doprecyzowano pojęcie czytania jako „rozumienie, wykorzystanie i refleksyjne przetwarzanie tekstów kultury”37. Wymieniono w niej również zalety czytania: wzbogaca słownictwo, ułatwia nazywanie uczuć i relacji między rówieśnikami, rozwija wyobraźnię (co między innymi umożliwia obiektywne spojrzenie na zachowania własne i innych), pozwala na lepsze radzenie sobie $\mathrm{z}$ funkcjonowaniem w szkole. Przytoczone zalety czytania wiążą się z przekonaniem, że uczniowie czytający sprawiają mniej kłopotów wychowawczych i lepiej radzą sobie z obowiązkiem szkolnym. To właśnie nauczyciel bibliotekarz powinien być najlepiej przygotowany do motywowania do czytania. Głośne czytanie, opowiadanie to podstawowe metody słowne, które wykorzystują bibliotekarze w swojej pracy. W podstawie programowej zauważono również, że można włączyć w to nauczycieli bibliotekarzy:

Uczeń powinien mieć zapewniony kontakt z książką, na przykład przez udział w zajęciach, na których czytane są na głos przez nauczycieli fragmenty lektur, lub udział w zajęciach prowadzonych w bibliotece szkolnej. W ten sposób rozwijane są kompetencje czytelnicze, które ukształtują nawyk czytania książek również w dorosłym życiu ${ }^{38}$.

$\begin{array}{ll}35 & \text { Ibidem, s. } 12 . \\ 36 & \text { Ibidem. } \\ 37 & \text { Ibidem. } \\ 38 & \text { Ibidem, s. } 13 .\end{array}$ 
Poza motywowaniem do czytania pojawił się jeszcze jeden obszar, w którym powinni dobrze sprawdzić się nauczyciele bibliotekarze — „wykorzystanie metod i technik wyodrębnionych z informatyki" ${ }^{39}$, ponieważ mają one być wykorzystane między innymi do zdobywania informacji z różnych źródeł. Uczniowie mają być przygotowani do korzystania z Internetu — do dokonywania świadomych i odpowiedzialnych wyborów, krytycznej analizy informacji, bezpiecznego przeszukiwania i relacji z innymi użytkownikami opartych na szacunku.

W podstawie programowej zwrócono uwagę na metodę projektu — jest to sposób pracy, który z sukcesem może być wykorzystywany przez nauczycieli bibliotekarzy ${ }^{40}$. Zakłada dużą samodzielność, co sprzyja indywidualnemu procesowi uczenia się. Projekty zespołowe wspierają integrację, uczą słuchania i rozwiązywania problemów, dochodzenia do kompromisów, czyli skutecznego komunikowania się. Uczestnicy projektu planują, organizują pracę, ale również dokonują samooceny. Międzydyscyplinarne działania obejmują różne przedmioty, często angażują rodziców, a nawet środowisko lokalne, mogą sprzyjać międzynarodowej współpracy. Na pierwszym etapie kształcenia uczniowie doskonalą umiejętność czytania i wypowiadania się na temat przeczytanych tekstów. Ponadto powinni korzystać z różnych źródeł informacji, na przykład atlasów, czasopism dla dzieci, słowników i encyklopedii czy zasobów Internetu. Na drugim etapie w samokształceniu pojawiła się umiejętność samodzielnego docierania do informacji, dokonywania ich selekcji, syntezy oraz wartościowania. Powinna być też rozwijana rzetelna umiejętność korzystania ze źródeł i szacunek dla cudzej własności intelektualnej. Ważnym elementem jest umiejętność efektywnego korzystania $\mathrm{z}$ technologii informacyjnych, między innymi w poszukiwaniu, porządkowaniu i wykorzystywaniu pozyskanych informacji.

$\mathrm{Z}$ nowej podstawy programowej usunięto stwierdzenie mówiące o roli biblioteki szkolnej w realizacji procesu dydaktyczno-wychowawczego, zawiera ona jednak treści, w których realizację powinni się włączyć nauczyciele bibliotekarze. Stawia przed nimi często całkiem nowe wyzwania. Powinni włączyć się w realizację podstaw programowych z języka polskiego, historii, informatyki, ale również fizyki, plastyki i wychowania do życia w rodzinie ${ }^{41}$.

Znaczenie bibliotek jako ważnej części szkoły wspierającej edukację zauważono już w okresie międzywojennym. Początkowo opieka nad biblioteką spoczywała na nauczycielach uczących w danej szkole. Sytuacja zmieniła się dopiero w latach siedemdziesiątych XX wieku, zaczęto zatrudniać wówczas nauczycieli bibliotekarzy, od których wymagano kwalifikacji bibliotekarskich i pedagogicz-

\section{Ibidem.}

40 D. Grabowska, Projekt jako metoda godna polecenia dla bibliotekarzy, [w:] Książka, biblioteka, informacja w kręgu kultury i edukacji, red. E.B. Zybert, D. Grabowska, Warszawa 2008, s. 242-250.

41 A. Puścińska, Nauczyciel bibliotekarz a nowa podstawa programowa, „Biblioteka w Szkole" 2017, nr 12, s. 5-8. 
nych. Treści, w realizację których może, a nawet powinien włączyć się bibliotekarz pracujący w szkole, pojawiały się we wszystkich programach: podstawach nauczania, przysposobieniu czytelniczym, ścieżkach edukacyjnych i podstawach programowych. Od wiedzy o książce i samokształcenia ewoluują one w kierunku kompetencji czytelniczych i informacyjnych. Nauczyciele bibliotekarze realizują zadania bibliotekarskie (gromadzą, opracowują, przechowują, informują), ale również pedagogiczne - wspierają realizację programów nauczania w szkole. Stawiane przed nimi zadania zmieniają się wraz z podstawami programowymi. Współcześnie ważne staje się kształtowanie motywacji czytelniczych, ale także kompetencji informacyjnych. Równie istotne są takie kompetencje, jak: kreatywność, innowacyjność, przedsiębiorczość, krytyczne i logiczne myślenie, rozumienie, argumentowanie, wnioskowanie, otwartość wobec świata i innych ludzi, świadome samokształcenie. Realizacja tych zadań powinna odbywać się z udziałem nauczyciela bibliotekarza, a jest to możliwe tylko przy współpracy z innymi nauczycielami.

\section{Bibliografia}

Andrzejewska J., Bibliotekarstwo szkolne. Teoria i praktyka, t. 1. Organizacja biblioteki, Wydaw. SBP, Warszawa 1996.

Białkowska E., Praca pedagogiczna z czytelnikami w bibliotece szkolnej, Warszawa 1964.

Bornsteinow J., Jak urządzić bibliotekę szkolna i domową?, Warszawa 1927.

Dąbrowska W., Biblioteka szkolna, Warszawa 1939.

Filipkowska-Szemplińska J., Organizacja bibliotek szkolnych, Warszawa 1930.

Grabowska D., Podstawa programowa inspiracja do wspótpracy nauczycieli bibliotekarzy z nauczycielami kształcenia zintegrowanego i języka polskiego, „Poradnik Bibliotekarza” 2013, nr 9, s. 4-10.

Grabowska D., Projekt jako metoda godna polecenia dla bibliotekarzy, [w:] Książka, biblioteka, informacja w kręgu kultury i edukacji, red. E.B. Zybert, D. Grabowska, Wyd. SBP, Warszawa 2008, s. 242-250.

Piotrowska R., Edukacja informacyjna w polskiej szkole, Wydaw. SBP, Warszawa 2011.

Program liceum ogólnoksztatcacego oraz liceum zawodowego i technikum. Przysposobienie czytelnicze i informacyjne, Wydawnictwa Szkolne i Pedagogiczne, Warszawa 1985.

Program nauczania ośmioklasowej szkoły podstawowej, Warszawa 1963.

Program nauczania ośmioklasowej szkoły podstawowej. Język polski: klasy V-VIII, Warszawa 1974.

Program nauczania w szkole podstawowej, Warszawa 1959.

Program ośmioklasowej szkoły podstawowej, Warszawa 1947.

Program szkoły podstawowej. Przysposobienie czytelnicze i informacyjne, Warszawa 1983.

Program szkoły podstawowej. Przysposobienie czytelnicze i informacyjne, Warszawa 1990.

Puścińska A., Nauczyciel bibliotekarz a nowa podstawa programowa, „Biblioteka w Szkole” 2017, nr 12, s. $5-8$.

Radlińska H., Książka wśród ludzi, Wydaw. SBP, Warszawa 2003.

Radlińska H., Zadania biblioteki szkolnej, Związek Księgarzy Polskich, Warszawa 1937.

Radziejowska A., Bibliotekarze szkolni — brak integracji zawodu, „Przegląd Biblioteczny” 1987, z. 3/4, s. 379-396. 
Radziejowska-Hilchen A., Edukacja czytelnicza i medialna, [w]: Ksiązka i biblioteka w środowisku edukacyjnym, Warszawa 2002, s. 139-152.

Staniów B., Biblioteka szkolna dzisiaj, Wydaw. SBP, Warszawa 2012.

Tłuczek P., Prowadzenie biblioteki szkolnej, Warszawa 1930.

\section{Akty prawne}

Rozporządzenie Ministra Edukacji Narodowej z dnia 15 lutego 1999 roku w sprawie podstawy programowej kształcenia ogólnego, Dz.U. 1999, nr 14, poz. 129.

Rozporządzenie Ministra Edukacji Narodowej z dnia 23 grudnia 2008 roku w sprawie podstawy programowej wychowania przedszkolnego oraz kształcenia ogólnego w poszczególnych typach szkół, Dz.U. 2009, nr 4, poz. 17.

Rozporządzenie Ministra Edukacji Narodowej z dnia 14 lutego 2017 roku w sprawie podstawy programowej wychowania przedszkolnego oraz podstawy programowej kształcenia ogólnego dla szkoły podstawowej, w tym dla uczniów z niepełnosprawnością intelektualną w stopniu umiarkowanym lub znacznym, kształcenia ogólnego dla szkoły specjalnej przysposabiającej do pracy oraz kształcenia ogólnego dla szkoły policealnej, Dz.U. z 24 lutego 2017 roku, poz. 356 .

\section{Evolution of tasks of librarian teachers in school didactics}

Summary

The article presents changes in tasks faced by teacher-librarians in their pedagogical activities. The following documents were analyzed: teaching principles, reading instructions, educational paths, and core curricula. They reveal the competencies and attitudes that children are to be taught by teacher-librarians. Teacher-librarians support curricula implementation, their tasks change along with the curricula. Nowadays development of not only reading motivation, but also information competencies is being emphasized.

KEYWORDS: school library, teacher-librarian, curricula 